\title{
Bureaucracy to Multi-personal Communication in Arthaśāstra: The System of Human Mediation
}

\author{
Siddhartha Chatterjee ${ }^{1}$
}

\begin{abstract}
Ancient Indian manuscripts bear the evidences of the communication patterns of traditional India. Since literature is the mirror of the society, it can also reflect the communication system of the society at the same time. When we study communication, we mainly go through the western theories and models. People hold the notion since communication study as an independent subject has been initiated in the west we should put our thrust upon their perceptions of the process of communication. In contrast to this radical view the author of the present article attempted to highlight an Indian style of communication process. The assumption is that perhaps the complex process of message discourse could be traced here.
\end{abstract}

The manuscript taken for this purpose is Arthaśāstra, a fine ancient book upon politics and economics, originally written by the ancient Indian scholar Käutilya or Chānakya. A historical study carried out to find out the communication process embeddedin various chapters of the book reveals some interesting points. The depiction of bureaucracy for seamless function of governance sub verses the structure of seamless communication, rather information transmission. The system of spy also echoes that the medium of communication was chiefly humans rather than material e.g. communication technology.

The complexity of the bureaucratic structure is the outcome of the complexity of the process of the communication. Interpersonal communication occurs at multiple layers within the system. The author after careful examination of all these aspects names it Multi-personal communication. Itis also seen that this Multi-personal communication was the foundation for the achievement of Mauriyan Empire's bahujanhitāya, bahujansukhāya cha, a manifestation of the theme of Sädhäranikaran. Its presence is still observable in modern societies.

Key words: - Indian communication, Communication process, Arthaśāstra,Chānakya, Bureaucracy, Multipersonal communication, Human mediation.

\section{Introduction}

Ancient Indian civilisation had a different social structure from today where the western influences have shaped the society we are living in. Message transmission took place at every layer from communicator to receiver through human mediation. At about 300 BC an Indian scholars namely Chānakyaor Kāutilya or Vișnugupta had authored a fine book of Economics and Political Science known as Arthaśästra. Apart from the central theme it can also be observed as a historical documentation of thee then sociopolitical structure. Every society, being it a traditional or modernmust have a well-defined communication system for message transmission within it. The western models of mid-20th century bear the note of two basic modes of

1. Part Time Lecturer, Department of Journalism and Mass Communication Tara Devi Harahk Chand Kankaria Jain College, Cossipore, Kolkata. and Guest Lecturer, Department of Journalism and Mass Communication Dum Dum Motijheel College, Dum Dum, West Bengal. message transmission. One is linear; for example, the model of Shannon and Weaver (Kumar, 2011). The other one is circular mode e.g. the Osgood and Schramm's model (Kumar, 2011). Surprisingly these models have become the paradigm of the process of communication since the beginning of communication as an independent field of study, even in Indian context also. What if we get the evidence of linear and circularprocess in our ancient Indian texts long before the western theorization?The existence of both communication modesat the time of Chanakyain the wake of the Mauryan Empire ${ }^{2}$ can be traced from Arthaśästra in the form of bureaucratic communication. The key element of this was human to human networks of message discourse.Max Weber, the German sociologist, pointed that bureaucracy constitutes the efficient and rational way in which one can organize human activity. Systematic processes and organized hierarchies were necessary to maintain order and maximize efficiency (Swedberg\&Agevall, 2005). The term 'bureaucracy' is a combination of French word 'bureau' with the Greek word 'kratos' which 
means political control originated from a desk or office. The French economist Jacques Claude Marie Vincent de Gournay coined the term in mid-18 th century $^{3}$. As a literary theme it was richly developed by Plato and Machiavelli which has the characteristic form of public administration, especially with extensive territorial sovereignty. In modern democracies like United States and other industrial nations, one sixth of the national income originates from bureaus. The activities of the bureaus dominate the front pages. The early forms of bureaucracy also have been observer in civilizations of Sumer and Egypt (Niskanen, 2007).In the subsequent paragraphs of this article an attempt has been made by the author to look back into the history and find out the major aspects of bureaucratic communication of early Indian society from the philosophy of Chānakya.

\section{The Dimensions}

Scholars interpreted Arthaśāstra in different ways. For example, R.P. Kangle (1997) said it as a "science of politics," a treatise to help a king in "the acquisition and protection of theearth".For A.L. Basham it is a "treatise on polity" (Boesche,2003). G.P. Singh said it to be a "science of polity" (Boesche, 2003). Roger Boesche(2003) held it as "science of political economy".Communication as an interrelated discipline with Sociology and Political Science must take into account and analyse the methods of message discourse hidden within its sciences. For this historical studyof the book Arthaśästra, the mostly available English translation by R. Shamasastry has been taken as the source material. In search of the communication process the Book-I; Chapter VIII, Chapter IX,Chapter XI and Book-II has been taken for re-observation. It has been considered as a book of Indian philosophy on politics, leadership, statecraft and economicsetc, originally written in Sanskrit. The book centrallyargues how in a state an efficient economy and political structure can be established. The apparent theme of discussion is the ethics of economics and the duties and obligations of anadministratorand the collective ethics of governance (Sen\&Basu, 2006).

\section{The Dimension of the Structural Bureaucracy}

The study is two dimensional. Dimension Ais structural and dimension $B$ is communicative. The former dimension is the direct approach of the text i.e. how to establish the institution of bureaucracy diplomatically.It is a blue-print of a regimented governing body. The latteris the dimension of communication process where messages flow within the framework of the institution of bureaucracy. The message transmission must be carried out with proper efforts which are capable tounite the people within the system. Before the analysis of dimension $B$ to understand their functional aspects, let us examine the dimension $\mathrm{A}$ from the document available.

NarasinghaProsadSil(1985) compared Chänakyawith the French philosopher Machiavelli [1469-1527] in terms of diplomatic theory and practice. Since Machiavelli provided a paradigm of diplomatic communication, Chānakyaon the other hand gave the concept of communication through the assembly of Māndala $\bar{a}^{4}$ long before Machiavelli. Many scholars argue Chanakyato be Machiavellian whereas this observation shows Machiavelli to be Chānakya-an. The reading of Arthaśāstrashowswhatthe later thought years ago the former fartherdevelopedto achieve the greater paradigm of diplomacy. Machiavelli frequently being damned as an amoral cynic has been synonymous with political deceit and the ruthless use of power (Sil, 1985). The distinction between him and Channakyais that, the later believed in the systematic use of power, highly based on morality even when exercising political deception for the benefit of his motherland. He considered the king not a ruthless ruler but a servant to his countrymen whose motto shall be bahujanhitāya, bahujansukhāya cha ${ }^{5}$ (Governance in Classic India, 2013)

The assembly of Mândala begins in the initial books and chapters of Arthaśástra. The Chapter VIII of Book-I is entitled as "the Creation of Ministers" as per Shamasastry's translation. It says that a king should employ such persons as his Ministers who can be trusted by him since he has personal knowledge of their honesty and capacity, whose secrets, possessed of in common, are well known tohim. They would never hurt him or else he would exploit their secrets. The king may also follow them in their good and bad acts. Faithfulness of his ministers should be testedby him under difficulties fatal to life and are oftried devotion. Their intelligence also must be tested.He shall appoint those who, when employed for financial matters, show as much as intelligence revenue(Shamasastry, 1914).

He shall employ as ministers those, whose fathers and grandfathers had been Ministersbefore ${ }^{6}$. Such persons in virtuousness of their knowledge of past events and of an established relationship with the king, will never desert him, although offended. Such faithfulness is seen even among dumb animals. For example, cows stand aside 
from strange cows and keep always company with their accustomed herds.Hence, he shall employ as ministers those who will regard the king as the real sceptre-bearer or dandadhara and do not offend him. Wisdom, purity of purpose, bravery and loyal feelings should be the qualifications for becoming a minister oramätyah. It is satisfactory in all respects to infer a man's ability from his capacity shown in his work. The spheres of their powers should be divided according to the differences of their working capacity; taken into consideration the place and time where and when they have to work (Shamasastry, 1914).

The Chapter-IX, under the title of "Creation of Councillors and Priests" says person from a good family and character, highly spoken off, well educated inVedās and the six Angas, skilful, well versed in the science of governance, obedient and who can prevent calamities providential or human by suggesting solutions prescribed in the Atharvaveda, should be as high priest. As a student his teacher, a son his father, and a servant his master, the king shall follow him (Shamasastry, 1914).

Book-II, which is "The Duties of Government Superintendents says there should be Superintendents in the sub-sections of the bureaucratic structure e.g. the department of revenue collection, accounting, treasury, forges, mines, store-houses, armoury, toll-taxes, commerce, forest produces, army, navy, immigration etc. Their position in the rank from the readings could be anticipated as next to the councillors (Shamasastry, 1914).

"The institution of Spies"has been depicted in Chapter-XI. This is the section for which Channakyashould be held as a great thinker ofbureaucratic institutional structure.The king should proceed to create spies tried under temptations in assistance of his council of ministers. They should be possessed of foresight and purity in character. Such spies should be under the guise of a disciple or käpatikachhátra, a recluse orudāsthita, a householder or grihapaitika, a merchant or vaidehaka, ascetic practising austerities ortāpasa, a class-mate/colleague or satri, a firebrand or tíkshna, a mendicant woman or bhikshuki and poison givers or rasadā such as a sauce-maker or súda, a cook or arälika, procurer of water for bathing or snapaka, shampooer, the spreader of bed or ästaraka, a barber or kalpaka, toilet-maker or prasādaka, a water-servant. servants such as have taken the appearance of hump-backed person, a dwarf, a pigmy or kirāta, the dumb, the deaf, the idiot, the blind; artisans such as actors, dancers, singers, players on musical instruments, buffoons, and a bard (Shamasastry, 1914). The interesting point to be noticed here is that he had the knowledge of good human resource management and persons with diverse qualities had a role to play in the structure. The discussion of the usage of spy has been brought here to clarify the brilliance of Chānakyaas a constructor of human medium. The characteristics of the institution have been described in the subsequent text.

A person skilful enoughto guess the minds of others is akapatikachhätra. He has to ascertain the purity of character of the king's servants working within the bureaucracy by collecting secret information about them(Shamasastry, 1914).

A recluse or udāsthita,provided withmuch money and lands shall carry on agriculture,cattle-rearing, and tradeetc. He should send his ascetics on espionage, ordering each ofthem to detect a particular kind of crime committed in connection with the king's wealth and to report of it when they come to receive their subsistence and wages. All the ascetics under the recluse shall severally send their followers on similar missions. A householder spyshall carry on the cultivation of lands allotted to him. Whenever any necessary secrete information leaks, he shall inform it to his employer immediately. Same shall be of a merchant spy.A traderspy shall carryon the manufacture of merchandise on lands allotted to him for the purpose and be alert of secret information. A man with shaved head or braided hair and desirous to earn livelihood is a spy under the guise of an ascetic practising austerities or tāpasa.Such a spy may wander in the suburbs of a city in search of information. The king or his minister shall conduct his affairs in conformity to the forecast made by the Spies. He shall appease with offer of wealthand honour to those who have had some well-known cause to be disaffected, and impose punishments in secret on those who are forno reason disaffected or who are plotting against the king (Shamasastry, 1914).

The chapter also talks about the wondering spies who shall be sent by the king to espy in his own country the movements of his ministers, priests, commanders of the army and other important government officials. Fiery spies, employed to hold the royal umbrella, vase, fan, and shoes, or to attend at the throne, chariot, and conveyance shall espy the public character ofthese officers.Classmate spies shall convey that information to the institutes of espionage. Women shall also espy the private character of these officers.Such a woman shall frequent the residences of the king's prime ministers or 
mahämātrakulāni. She shall convey any information collected to theinstitute of espionage (Shamasastry, 1914).

Spies not only did their jobs inside the country, but they also wandered in foreign lands to gather information about friendly countries as well as of enemies. The immediate officers of the institutes of espionage shall by making use of signs for writing ${ }^{7}$ or samjnälipibhihconduct the job of their spies. When the information thus received from different sources is exactly of the same version, it shall be held reliable. If they frequently differ, the information shall be considered invalid (Shamasastry, 1914).

\section{The Communicative Dimension}

The dimension $B$ i.e. the communicative dimension came out after the close analysis of these chapters in the book Arthaśāstra, it is seen that Chānakya's bureaucratic set up was not only meant for good administration, but it was a platform of seamless information transmission system. Perhaps the success of the Mauryan Empire was not only based upon the political structure but also upon the wonderful communication techniques as embedded in Arthaśāstra ${ }^{8}$. The observation has unfolded that persons engaged in the bureaucracy were trained to think, act and communicate in identical ways as per the institutional direction. Thus, efficiency achieved, and the possibility of message distortion was utterly narrow. The hierarchy replaces the ordinary social action-interaction with mutually defined meaning of bureaucratic action with the clear motto of bahujanhitāya, bahujansukhāya cha. Rationally organised actions lead to mutual understanding in which individuals try to achieve a common goal defined within the system. The goal was the establishment of an ideal state ${ }^{9}$.

The downward transmission of information from the king to the lower ranks in the system depicts the linear form of message transmission. Unlike the Shannon and Weavers model of linear mathematical communication process (Kumar, 2011) where the means of communication is technology, here the means are humans within the system of bureaucracy. The barrierhere is less mechanical but more semantic due to the wrong reception or misinterpretationof meaning (Andal, 2008). The probability of such misinterpretation is seen minimal here because of the rational set up of the human mediation in the dimension $\mathrm{A}$, discussed previously.

The model in fig: 1 , shows the linear mode of message transmission within the main course of governance as reflected in Arthaśästra. The assumption thus goes that the Mauryanrulers perhaps followed this model to carry out the ideal state's administrativediscourse.

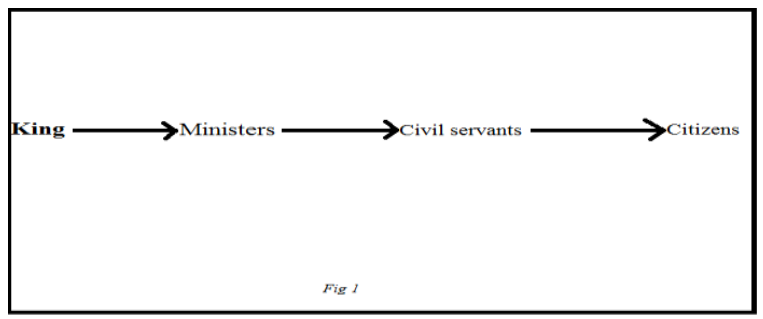

When the king [leader, if related to the modern democratic set up] is the sender and the minister is the receiver, the message is mediated by the king himself. When civil servants e.g. councillors or superintendents become receivers, the ministers become the medium. When citizens become the receiver at the end of the message transmission, the intermediate personnel become the medium of the message transmission. The process is multi layered; the direction is linear and chiefly human mediated. If compared to the Lasswell's model(Andal, 2008), the similarity is seen.Its existence is felt in every layer.

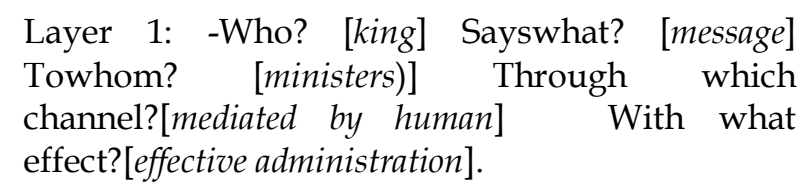

Layer 2: -Who? [minister] Sayswhat? [message] Towhom? [civil servants] Through which channel? [mediated by human] With what effect?[effective administration].

Layer 3: -Who? [civil servant] Sayswhat? [message] Towhom? [citizens] Through which channel?[mediated by human] With what effect?[effective administration].

A secondary mode of message transmission could be traced From the Chapter-XI of the Book-I.The institution of spy was a brilliant concept of Channakyato strengthen the structure of the government. It was a system of bureaucracy to transmit and receiveinformation at every point of the administration. It shows that the spies were present everywhere in the bureaucracy. Deployed by the king they shall stay with the officials, find out their activities and collect secret information about the conduct of their occupations, report back to the king. The mode of transmission is circular in nature [as shown in Fig: 2].The presence of the Circular model of Osgood and Schramm (Kumar, 2011) can also be detected.This is also human mediated. A Spy functions as the human medium here. At the time of receiving message from the king he becomes a receiver. The same person becomes the sender while communicating with officials. Back to the king the 
similar action occurs. Even the interpretation also takes place within intrapersonal level of all because of the understanding of the secret code is

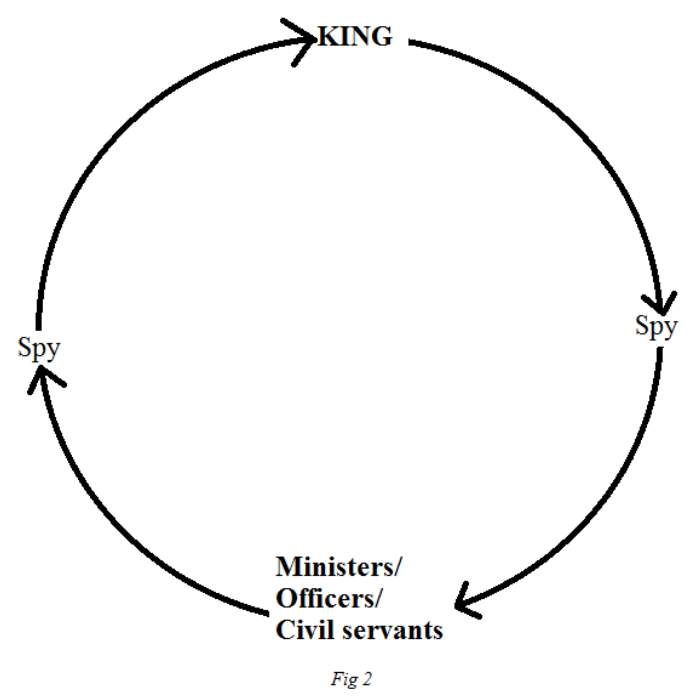

also involved here. Everyone in the system is encoder, interpreter and receiver.

The presence of feedback has also been firmly detected in circular mode. The linear mode discussed previously has very little chance of getting feedback to the king from his subjects and citizens because in linear administration a direct feedback is difficult. One-way information dominates over two-way communication. To eradicate this shortcoming, the spy mediated bureaucratic communication had been installed in the circular form. The credit obviously goes to Chänakyaand his foresight.

\section{The Multipersonal Communication}

Thus, the dimension $B$ i.e. the process of communication is observed very complex in nature.The complexity caused due to the existence of many interpersonal processes of information dispersion in multiple layers. Every individual layer has two different routes. One is linear route and the other is circular route. The number of points for message encoding, transmission and decoding in these layers are also multiple. Every point is occupied by human mediators.

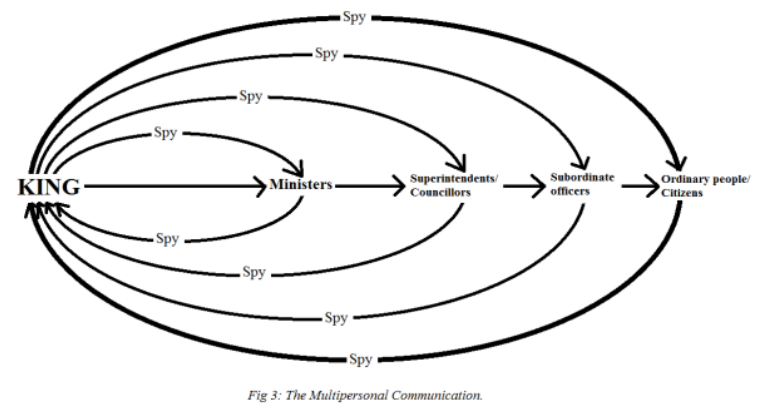

Infig 3 the diagram is the combined form of the diagrams shown in fig 1 and fig 2 . It delineates the complete bureaucratic communication structure of administration. Notably, spies are present at each layer in the system for message transmission to determine the accuracy of the system by communicating the feedback. They function identically with a common frame of reference. In the model of Berlo it has been held that interpersonal communication can take place within the similar frame of reference(Andal, 2008). In such level of communication, the communicator and receiver work within same context. Even the circular model of Schramm also echoes the concept of contextual familiarity. Here in this instance of communication process decryptedfromArthaśāstradenotes the multipointed communication within one context. The author has identified it as Multi-personal communication. The followings are its characteristics: -

1) It is human mediated.

2) It is multi layered.

3) The direction of message flow islineo-circular.

4) It is complex.

So, the human mediated communication where the message is transmitted layer by layer through lineo-circular way to achieve the reception of common meaning is called Multi-personal communication. The commonality orSäahäranikaran ${ }^{10}(G h o s h, 2009)$ is achieved by minimising the chances of message distortion.

\section{Conclusion}

At the concluding part it is important to discuss its viability in our present Indian context.It istrue that Arthaśästra has been considered as the ideal political bible for many centuries. India's former National Security Advisor Mr.Shiv Shankar Menon praised Arthaśāstra in October 2012 for its clear and precise rules.He recommended furthermore, reading of the book for broadening the vision on strategic issues which are relevant even today ${ }^{11}$.The relevance of its applicability can also be felt in the field of communication studies to find out the truth about systematic functional order within governance. As mentioned previously, this paper aims to show the prospects of human mediated communication. To illustrate the central theme of discussion the concept of spy and bureaucracy has been taken as examples from the book. It performed as a watch dog to keep eyes upon the merits and demerits of the officials engaged in the system of governance through message transmission and feedback. It could have 
resulted into immediate reinforcement of the merits as well as debugging the flaws discovered.

The western communication studies advocate the usage of advanced communication technologies in order to achieve the clarity of message reception. The technological determinism (Kumar, 2011) argued that the development of communication is determined by the development of media technology. The chief proponents of Toronto School of Communication believed that the medium shapes the participants of communication in any civilization (McQuail, 2005). The mass society theory also held that it is the media that has the power to rule over its users. Our study of human mediated communication has an opposed viewpoint to such western concept of media supremacy. No matter how advances the media technology is, it has to be operated by the users at the encoding and decoding points. It is a human who decides what media is to be chosen for the desired response from another human. So, the role of human cannot be ignored in the communication process. Whether it is a traditional society or a mass society, human mediation appears at the first stage and technological mediation comes second.

The intention of the author is not to oppose the technological development but to advocate the growth of human mediated communication along with that. India as a severely populated country with low literacy rate will need more time to become completely technologically equipped unlike other western technologically developed countries. Most of the rural areas of India are still devoid of technological awareness. The impact of traditional society still could be felt in some parts of northern regions. What we have is vast human capital. With slow pace of technological development here we can simultaneously use the human mediate Multi-personal communication for mass awareness and good governance. In fact, it has been practiced from the early ages but not has been researched enough in comparison to communication technology.

Thus, human mediation demands major analytical studies in Indian communication studies. Indian classical manuscripts have many examples of human mediation of information. The book Arthaśästraaccumulated some of them and illustrated them beautifully. However, the time when its theories were put into practice was different from our times. After independence governing a country like India with more than 1.250 billion population has always been a challenge to its political leaders. A democracy constituted of so many political parties suffers from a major crisis of opinion diversity. Sometimes the elected government bodies forget bahujanhitāya, bahujansukhāya chaand indulge into political chaos. This happens due to lack of perfection in human mediated communication and properMulti-personal communication. We should recount that Sādhäranikaran in ancient Indiahad beenachievedthrough human mediation.

[Acknowledgement: -The paper was presented at Asian Congress of Media and Communication, Kolkata Chapter in November 2015. And won MahārishiPānini Award i.e. second-best paper presentation award in the same congress]

\section{Notes: -}

1. These names are traditionally recognised as other names of Chānakya.

2. The Mauriyan Empire was established by King ChandragptaMurya. The last ruler was King Ashoka. The Iron Age kingdom existed from 322-185 BCE.

3. The definition of bureaucracy has been given in the Merriam Webster dictionary.

4. It is a concept by Chänakya which originally means the assembled personnel who function as conductors of Bureaucracy.

5. Originally it is mentioned in Rigveda which translates to, "for the good and welfare of many." Later Chānakya echoed this statement as the architect of the great Mauryan Empire in fourth century BC.

6. The evidence of transpersonal relationship, the level where communication takes place with ancestors is present in Arthaśästra.

7. The secret code is a symbolic code. It is different from the ordinary language and encoded on its own terms. The proper decoding of meaning at the reception point brings out the desired meaning. In communication studies it is known as Semiology; the study of signs and symbols, a term given by Ferdinand De Saussure. Its existence is seen within the institution of spies. Long before Saussure termed it as an independent field of linguistic studies.

8. History bears its evidences that Channakya was the teacher of King ChandraguptaMaurya. His vision and wisdom could bring in the fall of the Nanda Dynasty and subsequent establishment of the Mauryan Empire.

9. In Chānakyas word it was ädarshaSāmrājya or the ideal kingdom. 
10. Sädhāranikaran is an Indian communication philosophy. The word Sädhäran means common.

11. Published in "India needs to develop its own doctrine for strategic autonomy: NSA". Economic Times (NEW DELHI). PTI. 18 October 2012. Retrieved 18 October 2012.

\section{References: -}

Andal, N. (2008). Communication Theories and Models. Mumbai: Himalaya Publishing House.

Boesche, R. (2003). Kāutilya'sArthaśāstra on War and Diplomacy in Ancient India.TheJournal of Military History, 67 (1), 9-37.

Governance in Classic India (2013). Towards Improving Governance: New Delhi: Transparency International India.

Ghosh, S. (2009). Mass Communication an Indian perspective. Kolkata: SahityaSamsad.
Kangle, R. P. (1997).Kāutilya'sArthashastra, 3 vols. Laurier.

Kumar, K. J. (2011). Mass Communication in India. New Delhi: Jaico.

McQuail, D. (2005). Mass Communication Theory. London: Sage.

Niskanen, W. A. (2007). Bureaucracy and Representative Government. USA: Aldine transaction.

Sen, R.K.,Basu, R.L.(2006). Economics in Arthashastra. New Delhi: Deep and Deep.

Shamasastry, R. (1915). Kāutilya'sArthashastra. Mysore: Oriental Research Institute.

Sil, N. P. (1985).Kāutilya'sArthashastra: A comparative Study. Academic Publishers.

Swedberg, R.,Agevall, O. (2005). The Max Weber dictionary: key words and central concepts. Stanford University Press. 